\title{
1. The rise of an unstable century
}

At the dawn of the twentieth century, the European powers confronted two major geopolitical weaknesses. The first one related to the future of the Tsarist Empire, the second to the escalating fragmentation of the so-called "sick man of Europe", that is, the Ottoman Empire and, broadly speaking, the Balkan Peninsula.

In reality, since 1809 , the European powers were concerned about a potential "booming revolution" in the Tsarist Empire. ${ }^{1}$ The debates were vivid among intellectuals and in political circles, but they reached their peak when the 1905 revolution threatened, for a while, the implosion of Russia and the stability of Europe.

Until that moment, reactionary circles feared that any reform - including those introduced during the Enlightenment, those dealing with the educational reform, and those related to the foundation of the Academy - would encourage the lower popular strata and potentially most of the peasants to a rebellion. Joseph de Maistre and the Marquis de Coustine, for example, as well as the Slavophiles in Russia belonged to this mainstream. Others, by contrast, believed that the autocratic regime, particularly promoted by Nicholas I, was so refractory to any reform that the only way to achieve change was by revolution. From Narodniks to Anarchists and Marxists, several schools of thought, both in Russia and in Western Europe, nurtured that belief. To a large extent, these opinions were mainly connected to the unbalanced social relations in the Tsarist Empire, that is, the polarization between landowners and peasantry, as well as the industrial - and the broader economic - backwardness of the country.

Curiously, this was despite the activism of the Polish szlachta and the sympathy of Western Europe for the Polish aristocracy because of their courageous activities for the independence of the country. The question of the nationalities in the Tsarist Empire was perceived as less acute. This was probably because of the powerful Russian army and its reputation since defeating Napoleon, a reputation that lasted at least until the Crimean War.

See the letter of Joseph de Maistre to King Vittorio Emanuele I of December 1809 quoted by Dieter Groh, La Russia e l'autocoscienza d'Europa, Torino: Einaudi, 1980, pp.122-3, from Joseph de Maistre, Oeuvres Complètes, Lyon: Vitté et Perussel, 1884, XI, pp. 375 and 407. 
Nevertheless, the issue gradually appeared in the second half of the nineteenth century, affecting in different ways the empire's Baltic provinces. Even so, the year 1905 represented the crucial turning point when the radicalization of feelings and projects rapidly accelerated.

Until that moment, the heterogeneity of national groups in tsarist Russia made of that empire a mosaic of relations. The situation of the Lithuanian governorates, for instance, was not comparable with that of the Latvian and Estonian provinces, much less the Grand Duchy of Finland. Suffice it to remember that, in addition to Russian domination, Lithuanians shared interactive networks with Poles, Belarusians and, partially, with Ukrainians. Latvians and Estonians had to cope with a powerful German nobility, while the Finnish inhabitants had their Swedish lords. Because of this multi-hierarchical and diversified ethno-national structure, the various populations did not, at least at first, identify tsarist Russia as the main oppressive power. Instead, the government in St Petersburg did not apply policies that were perceived as a direct cultural threat to the different groups living in the Baltic provinces, although censorship and periods of political persecution occurred frequently.

In fact, after annexing a territory, Russia usually initially ruled on the basis of pre-existing laws, only gradually replacing them with Russian norms. This had a significant impact in Finland. The peasants were freeholders of small parcels of land. Together with the educated Swedish population, including the aristocrats who remained basically loyal to the tsar, they were able to preserve the Grand Duchy of Finland until 1917. This occurred despite the fact that the degree of autonomy varied over the years. Also, the increasing presence of Russian nobles modified power relations to a large extent, particularly in the countryside, to the detriment of the local peasants.

Linguistically, only peasants used Finnish, while the language of public administration, culture and arts was Swedish until the first years after independence. Still, the Finns began to develop a national epic in the 1830s. Later, the Russian bureaucracy supported the use of the Finnish language as a means to reduce Swedish influence in society. During these years, a Finnish nationalist movement became active. However, the activists soon followed divergent patterns, either focusing on language protection and social conservativism or demanding independence from Russia. The dissemination of socialist ideas had an additional impact in the Grand Duchy, although, even in this case, a divide grew between those who focused on the class struggle and those who emphasized the national question.

As for the Lithuanians, as mentioned above, they participated in the nineteenth-century Polish uprisings, along with some of the Belarusians and Ukrainians. Together with Latgalians, they contributed to rebellions 
against Russian rule, although arguments among insurgents were not lacking. Probably because the Lithuanians did not have a written language until the sixteenth century, their nobility often used a Slavic dialect not so distant from that spoken by Belarusians. The result was a belief among scholars in Belarus that the GDL was, in fact, a Belarusian state. A recent, very stimulating comparative study of Lithuanian and Belarus youth has confirmed the difference in understanding that these two groups have about their common past (Kamuntavičius 2014, pp. 75-98).

Furthermore, for a long time, the Lithuanian nobility resisted giving up manifestations of ancient paganism, even when they accepted Christianity. Later, most of their families shifted between the Orthodox and the Catholic religions. This was, for instance, the case of the Czartoryski family, which was originally Orthodox. All of these factors probably contributed to the development of religious tolerance within the GDL. At the same time, these elements reinforced an external perception of the Lithuanians as a people with a "fluid and undefined" identity. They encouraged identity with other Slavic peoples (Belarusians) or the Poles. Meanwhile, Lithuanian historians critically emphasized that the autonomy of the GDL significantly diminished after the Lublin Union in 1569. In the end, all of these arguments resurfaced during the nineteenth century, when the language issue became more relevant. A more accurate profile of the Lithuanians emerged, strengthening the position of those intellectuals who, advocating the uniqueness of their linguistic nation, rejected the idea of the re-establishment of the Commonwealth with Poland.

This ambivalence in the bilateral relations between Lithuanians and Poles persisted into the following decades of the nineteenth century, despite their cooperation in the anti-Russian resistance, while Estonians and Latvians were experimenting with more peaceful developments. In their case the German nobility played a crucial role. They had long enjoyed benefits and respect from tsarist Russia. They held leading positions in the local administrative bodies and their youngest sons could pursue military careers, a privilege granted by the tsars since Peter the Great. In return, Russia could rely on their loyalty. Locally, therefore, the relationship between the German nobility and the peasantry (mainly Latvian or Estonian) significantly marked the social and political dynamics.

In truth, the liberation from serfdom took place in these regions at least forty years earlier than in Russia (and Lithuania). Nevertheless, the peasants did not receive any land. Forced, therefore, to search for employment as farm workers, their discontent grew until the moment when a wide rebellion exploded in 1905.

Meanwhile, from the political-cultural point of view, St Petersburg was considered by the nationalists of these Baltic regions as a protector against 
the Germans. In the municipal elections of Riga, for instance, Latvians and Russians joined in a coalition against the Germans until the turn of the century. Their alliance collapsed exactly at the time when Latvian nationhood became a bone of contention with the Russians as well. But at least, until the last decades of the nineteenth century, the Estonian and Latvian national questions were locally perceived more as a problem of emancipation from the German-speaking nobility than from Russia.

The situation altered significantly during the reign of the last two tsars, Alexander III and Nicholas II. Their policy of Russification threatened, at least initially, the Germans' privileges. Changes in the administrative system, especially urban and judicial reforms, ideally offered an opportunity to treat the Baltic peoples equally. However, the Russian bureaucracy did not understand the local languages. Furthermore, the Russification policy encouraged the Orthodox Church to become more aggressive against Lutherans, Catholics and Muslims by intensifying its conversion efforts. Additionally, an assimilation policy was carried out in language, journalism and education, either by replacing non-Russian speakers in the administration and schools, or by increasing censorship and expanding Russian culture to the detriment of the local ones. This policy met with fierce resistance from the local intelligentsia, non-Orthodox believers, the German aristocracy, and liberals.

Particularly in the Polish and Lithuanian governorates, Russian authorities tried to impose the Cyrillic alphabet, banning the use of the Latin alphabet in books and any other publications. In addition, corporal punishment was introduced for youngsters who publicly spoke in their mother tongue. In reaction, Catholic priests began to finance, and then illegally transport into Lithuania, books printed abroad in the Lithuanian language; their example was followed by activists of secret organizations, who produced a widespread (and culturally interesting) phenomenon of book smuggling, which lasted for forty years (Kasekamp 2010).

The result of these events, and the broader revolution that affected Russia in 1905 after its humiliating defeat in the war against Japan, had a remarkable impact on the Baltic provinces. The rebels claimed social, political and cultural rights. Violence erupted particularly in Latvia against both landlords (Germans and Russians) and the tsarist police. The driving force of the protests was social inequality (rather than a demand for national and cultural liberties). This offered the Latvian Social-Democratic Union an opportunity to play a key role. Ideologically inspired by Marxist texts and German philosophy, the Union enjoyed broad support especially among the numerous and determined proletariat. As strikes and uprising in the countryside intensified, the German aristocracy appealed to the Russian Army. The Cossacks were sent, and a bloody repression followed. 
In Estonia, where the proletariat was also strong, the level of bloodshed was lower. However, social resentments merged vigorously with constitutional, autonomous and cultural claims. Even in Estonia, the landlords became the main target of violence, which led them to support the restoration of the imperial order at any cost.

In the end, when the revolution failed, the social fractures between the German aristocracy on the one hand and local workers and peasants on the other were so deep that prospects for a compromise were dim. At the same time, however, the anti-Russian feelings were also exacerbated to such an extent that the tsar lost the opportunity to exploit the divide et impera policy to his benefit.

The 1905 revolution in Lithuania was not distinguished by remarkable peasant uprisings against their landowners as in the other northern Baltic provinces, with some exceptions in the southwest of the country. On the contrary, the protests reflected visible national demands rather than socially-oriented claims, mainly because the proletariat was smaller in this area. The broader Russian revolution was here understood as the most effective occasion for summoning a Great Assembly (Seimas) in Vilnius. Demands for political autonomy within the Russian Empire (to be achieved by peaceful means) and the free use of language in the schools were discussed and included in a formal resolution (Mole 2012, pp. 36-7).

Significantly, the event was also followed by a critical declaration against the Polish ecclesiastic leadership of Vilnius, which had rejected the use of Lithuanian in religious services. After the Great Assembly, replacements of Russian with Lithuanian personnel took place in the administration and the schools of the governorates of Kaunas, Suwałki, and Vilnius. The Russian reaction, after a while, was to restore the previous situation. This policy was actually imposed to a large extent without violence, but it was followed by hundreds of death sentences, and thousands of arrests of nationalist activists, or their deportation to Siberia.

Despite its outcomes, the revolutionary experience of 1905 had farreaching consequences in many respects. First, it generated political parties whose commitment in the years to follow was to galvanize national claims within the population, and particularly among the peasants. Second, the goal of re-establishing the GDL was abandoned, at least among Lithuanians. Third, the Lithuanian relations with the Poles deteriorated further, actually beginning gradually since the failure of the 1863 insurrection. The unenthusiastic support expressed at that time by the tiny Lithuanian-speaking urban intelligentsia triggered serious repercussions in their relations with Polish nationalists, who accused them of contributing to the division of the anti-Russian opposition and even of playing the "tsarist game". Additionally, the Catholic Church in Poland widely supported the 
"polonization" of Lithuania during the last centuries. Despite the fact that Catholicism was an integral part of the Lithuanian national identity, this fact produced a disturbing feeling in the Lithuanian nationalists, particularly among extremist activists (Aleksandravičius 2016).

As a result, Polish-Lithuanian relations historically evolved at the turn of the century following divergent patterns. The 1905 Russian revolution revealed how this process was advancing. In fact, when the Seimas was taking place in Vilnius, riots occurred in Polish provinces, the most serious one in Łódź . In this context, the social dimension of the protests soon became obvious. On the one side was the Socialist Party, led by Józef Piłsudski, and on the other side was the significantly titled "SocialDemocracy of the Kingdom of Poland and Lithuania". The latter, led by Rosa Luxemburg, called for a general strike, together with the powerful Jewish labor organization "the Bund" that was founded in Vilnius in 1897.

In other words, although Lithuania was slowly but resolutely moving toward an autonomous perspective, most of the Poles and the Jews (irrespective of their political orientation) were still anchored to the idea of a resurgent Commonwealth. This situation left room for conflicting selfidentities and loyalties, which would have far-reaching consequences when World War I drastically and unexpectedly changed the European geopolitical framework.

Ukrainian nationalism experienced a different and more complicated trajectory, not only because the Ukrainian lands were included in both the Austrian and Tsarist Empires, but also because the Polish and Cossack aristocracies maintained a substantial influence in different Ukrainian regions during the nineteenth century.

The Cossack nobles, in particular, struggled repeatedly to attain equal status with the Russian nobility (dvorjanstvo). Since the eighteenth century, the local intelligentsia encouraged folklore, folk songs and history, or even more, chronicles with an emphasis on the Ukrainian past and autochthonous cultures, although in the Russian language. As Paul Magocsi emphasized in his monumental book on Ukrainian history, Ukraine (at that time called "Little Russia") was widely considered as an "integral part of the Russian imperial world" (Magocsi 1997, p. 356). Under these conditions, the development of the Ukrainian language and literature remained limited. This was the case despite some initial tsarist support for local education, and the opening of universities in Kharkov and Kiev. Classes there were often conducted in German, French or Latin, in addition to Russian, for the training of the empire's future bureaucrats. On the other hand, the plurality of this social structure was consistent with Russian imperial characteristics, naturally producing multiple loyalties. Furthermore, these loyalties turned into ethnic identities, whose multiplicity represented a 
specific peculiarity of the Russian/Ukrainian intercultural world, where the borders were indeed fluid and undefined.

Nevertheless, in the Western provinces on the Right Bank of the river Dnieper, the Polish cultural impact was so vividly accepted that the local nobles actively participated in the 1830-31 uprising. As a reaction, in the later years of the reign of Nicholas I, Count Sergey Uvarov disbanded the polonophile school system of the Western regions of Ukraine. He replaced it with a strategy aimed to promote local professional staff, Slavic studies, and historical research on "Little Russia", believing that this was the best way to integrate the Ukrainian provinces into the Russian Empire.

Meanwhile, in the mid-nineteenth century, an alternative approach was nurtured by some other intellectuals, such as the historian Mykola Markevych or the poet Taras Shevchenko. Their works radically detached Ukraine from Russia. They claimed that Kievan Rus' provided the roots of Ukrainian statehood. Focusing on the uniqueness of the Ukrainian identity, they depicted the Ukrainian people as subjugated and oppressed by both Russians and Poles.

Since then, the dichotomy between the Ukrainians' multiple and unique identities increasingly marked cultural relations in the West Bank. Originally, however, the process of raising a distinguished Ukrainian identity concerned the relations with expanding Polish nationalism, which promoted a "Ukrainian school" of Polish writers. Moreover, and anticipating a legendary narodnik public movement, the young Polish gentry encouraged a sort of "go to the people movement" in support of peasant emancipation and their "polonization". By contrast, Polish identity was rejected on the eve of the 1863 insurrection by a growing number of ethnographers, linguists and economists, who advocated the uniqueness of the Ukrainian identity.

In the meantime, the 1863 Polish uprising enhanced the tsarist reaction against any perceived threat of state partition. As a result, after the initial embrace of the Ukrainian or Little Russian movement, the tsarist reaction radically changed in the second half of the century. The State carried out a Russification policy (as in the Baltic area). Between 1863 and 1876, two main legal acts, the Valuev decree and the Ems Ukase, prohibited any publication in Ukrainian or, as they were called, "Little Russian dialects". Moreover, nationalist activists were arrested and some professors dismissed.

It was only at the end of the century that the first Ukrainian parties were established, although illegally. But the first significant turning point occurred during the 1905 revolution, which also affected Ukraine. Initially, the protests were at bottom predominantly about economic and social problems, with strikes in the factories and local soviets quickly multiplying 
in Kiev, Eastern Ukraine (Lugansk and Mariupol), but also in the South, and particularly in Odessa. Even peasants participated in the uprising, especially in the regions on the Western side of the Dnieper River.

During this turmoil, however, a national-cultural meaning emerged, which, prospectively, had a great impact on the development of the region. Indeed, the Imperial Academy of Science in St Petersburg suggested rescinding the language restrictions on the use of Ukrainian, by rejecting de facto the thesis that Ukrainian was a mere Russian vernacular.

The proposal did not have any legal effect because the Ems Ukase remained in force, but it did pave the way for printing, for the first time, a daily newspaper and several periodicals in Ukrainian in a number of urban centers from Kiev to Kharkov and Odessa. In 1906, the tsarist reaction substantially restricted Ukrainian language publications and discouraged any educational activity in languages other than Russian. Nevertheless, the short-term developments of the 1905 revolution that concerned the national dimension in Ukraine strengthened the expectations and mobilized local nationalist activists in the years to come (Magocsi 1997, pp. 380-81).

On the other hand, as previously stressed, the instability that was marking the dawn of the twentieth century was not exclusive to the Tsarist Empire. In fact, Russia had to cope with its military and industrial weakness in the Pacific Ocean against the new aggressive power of Japan, as well as with the social and political discontent within the country. Other places in Europe were simultaneously experiencing significant unrest, particularly the Balkans, where the Ottoman Empire had began its centurylong decline, attracting the attention of a number of political players, both "great" and "small" states.

Like hungry vultures, they eyed the Sublime Porte, whose dismemberment was considered just a matter of time. However, while the Tsarist and Ottoman Empires were both declining, there was an evident difference in their situations. Despite the military defeat in Asia and the 1905 revolution in Russia, the international arena considered the decrepitude of the Turkish Empire by far the most promising area from which to take profit. They looked for advantage in the geopolitical strategic realm, connected to the communication lines of Central Europe, the Eastern Mediterranean and the Indian Ocean. They also took account of the chaos within the small nations living within the Ottoman Empire, which offered the possibility for international military or police intervention.

Such was not the case with Russia, whose domestic and international institutional policies had not yet undermined the legitimacy of the state. In fact, the social unrest of 1905 was under control and a parliamentary reform was passed. Simultaneously, the national uprisings moderated their 
claims to national autonomy within the Empire, rather than radicalizing their demands for independence, except for Poland (whatever territory the term implied). Truly, from hindsight one can conclude that the 1905 revolution was simply a prelude to the following one, but, at the time, governments could not perceive this.

The situation in the Balkans was different. The Balkan national movements' demands for self-determination were unquestionably about state independence only, and not a "mere" democratic participation in the decision-making system of the existing Empire by the "subjugated nations". Such inflammatory claims were promoted since the first Serbian uprising of 1804, frequently forcing the South East European peninsula to adjust its political maps.

As a result, at the turn of the century, the Balkans included four recognized independent states, Serbia, Montenegro, Romania and Greece, which were unsatisfied about their territorial arrangements, as well as the Bulgarian principality, formally still a vassal of the Ottoman Empire. Moreover, Bosnia-Herzegovina was occupied by the Austro-Hungarian Empire, under a European mandate formulated at the Congress of Berlin in 1878, while formally still belonging to the Sublime Porte. Furthermore, Austro-Hungarian troops were permitted in the Sanjak (or Sandžak) of Novi Pazar, even though this region was also still formally under Ottoman sovereignty. In the end, the island of Crete functioned de facto as an independent state with an Assembly in Canea when the Ottoman troops withdrew in 1898 after a series of rebellions. However, the United Kingdom, which opposed any further weakening of the Sublime Porte, did not allow the Greek annexation of the island.

This was the situation at the beginning of the twentieth century, and it did not look promising for peaceful developments. In particular, the most controversial issue was connected to the future of a wider area, called Macedonia, which was located in the core of what remained of the European part of the Ottoman Empire.

In fact, the antithetical projects of Macedonian national selfdetermination nurtured by the various independent Balkan countries meant that the borders of the region and the identity of the peoples living there quickly became a battleground. Competing nationalist movements (supported by Greece, Bulgaria, Serbia and Romania) were increasingly very active in promoting their own educational programs, secret societies and conspiracies.

Furthermore, as an autonomist Macedonian national movement also began to develop, conflicts among the parties interested in taking control over the region intensified. Consequently, acts of revenge, assassinations and rebellions in Rumelia shook the Ottoman Empire at the turn of the 
century, giving the European Great Powers yet another opportunity to intervene on the basis of the 1903 Austro-Hungarian ${ }^{2}$ agreement with Russia in Mürzsteg.

Anticipating the establishment of modern peacemaking missions in deeply divided societies, the agreement authorized the deployment of an international police force side by side with the Sultan's regular police in order to preserve public order and stability in this region. However, this policy was the least suitable to facilitate this task, regardless of the fact that another step in downgrading Ottoman sovereignty in South East Europe was implemented (in fact the agreement was imposed on Turkey) (Akhund 2014, pp. 587-608).

In the end, the international intervention failed in achieving its goal.

Unrest, assassinations, sabotage, strikes and disorders resolutely continued until 1908, patently showing the total inadequacy of the international mission. In this chaotic situation, fearing a Macedonian partition to the detriment of the Ottoman Empire, the military officers belonging to the Young Turks association started a revolution in the Balkans. The rebellion rapidly expanded and imposed on the Sultan the return to the 1876 Constitution, a multi-party system, and a constitutional monarchy.

Nevertheless, the rebellion encouraged the Turkish tributary state of Bulgaria to take this opportunity to declare independence and elevate the principality into a kingdom. In turn, the Austro-Hungarian Empire considered these events an excellent excuse to change the regional balance of power by formally annexing Bosnia and Herzegovina. Greece followed by establishing a union with the Cretan State, while the Sandžak of Novi Pazar was returned by Vienna to Constantinople or Kostantiniyye (as the Ottoman capital was still called, along with İstanbul, until 1923). The hope, rapidly frustrated, was that this act would guarantee broader international consent to the geopolitical violations unilaterally carried out in the region.

The impact of these developments was, instead, devastating.

A new blow was dealt to relations between the Great Empires and their national groups, particularly within the Austro-Hungarian and the Ottoman Empires. In the first case, and despite initial disagreements between some Croatian and Serbian activists, a new and powerful Slavic solidarity became popular, particularly among the younger generation. A Croatian-Serbian coalition, established in 1903 under the leadership of

2 The Habsburg Empire changed its official name to the Austro-Hungarian Empire (or Dual Monarchy) after the Ausgleich with the Hungarian magnates in 1867, following the military defeats in Italy and Germany as well as the need to overcome the absolutism, imposed in 1849 after the crackdown on the Hungarian revolution. 


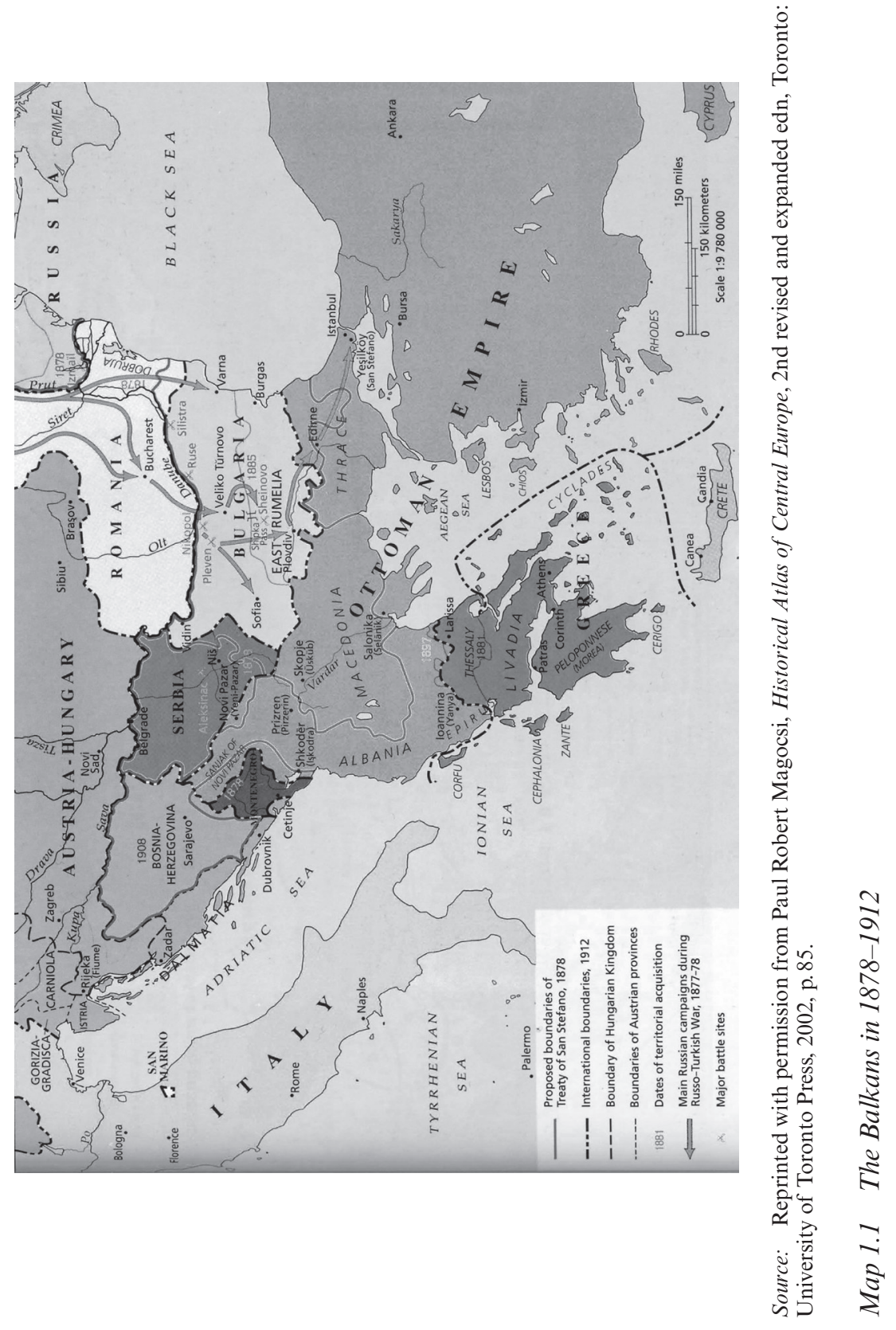


Frano Supilo and later Svetozar Pribićević, was able to govern Croatia, Slavonia and Dalmatia until 1918.

By contrast, in the second case, the polarization within the Young Turks movement quickly deepened between a liberal component with a patriotic and pro-Western vision on the one hand, and the extreme nationalists, supporters of centralization and a cooperation with Islamic fundamentalists, on the other. They radically disagreed on how to save the Ottoman Empire. Their irreconcilable visions exacerbated the pre-existing social fractures, leading to conflicts with such other national groups as the Armenians, the Slavs, the Albanians, the Arabs and the Greeks.

The turmoil within the Ottoman Empire created more favorable conditions for setting up a Balkan League. After several failed attempts, a political convergence of the small states in South Eastern Europe appeared to be achievable for the first time. The weakening of the Sublime Porte, as a result of the loss of Libya in the war against Italy in 1911, encouraged war-prone Montenegro to begin the conflict in the fall of 1912. Shortly thereafter, Serbia, Bulgaria and Greece militarily intervened in support of Cetinje and in a few months the first Balkan War culminated in the almost complete expulsion of Turkey from Europe.

This event alarmed the Great Powers, because, for the first time, the small Balkan states demonstrated their ability to initiate a radical geopolitical change in a crucial area for the interests of the Great Powers, without consulting and involving the latter. In fact, the potential partition of the Ottoman Europe among the winners would have affected German interests in building the Berlin-Baghdad railroad; the Austro-Hungarian expansion southward after the loss of Italy; Italian, Russian and French penetration into the Balkans; and the protection of British interests in the Eastern Mediterranean and Suez.

In summary, the Great Powers needed to interfere quickly regarding territorial arrangements. Therefore, and despite the fact that they had so far ignored the Albanian question, they decided to take into consideration the claims for self-determination of the Albanians, who had thus far been neglected by the Balkan winners. Consequently, the Great Powers took a stance in support of Albanian autonomy (not independence) at the peace conference in London, sharply dividing the Balkan League. Subsequently, new tensions arose on the ground, until Bulgaria decided to attack the Serbian army, starting the second Balkan War in June 1913. Militarily isolated in the region, Bulgaria could resist the Serbian, Greek, Romanian and Ottoman assaults for only a few weeks. Its defeat led to the Bucharest peace treaty, which established new regional borders. Bulgaria lost the southern Dobruja region to Romania, but - still more importantly - its aspirations regarding Vardar Macedonia were thwarted, to the advantage 


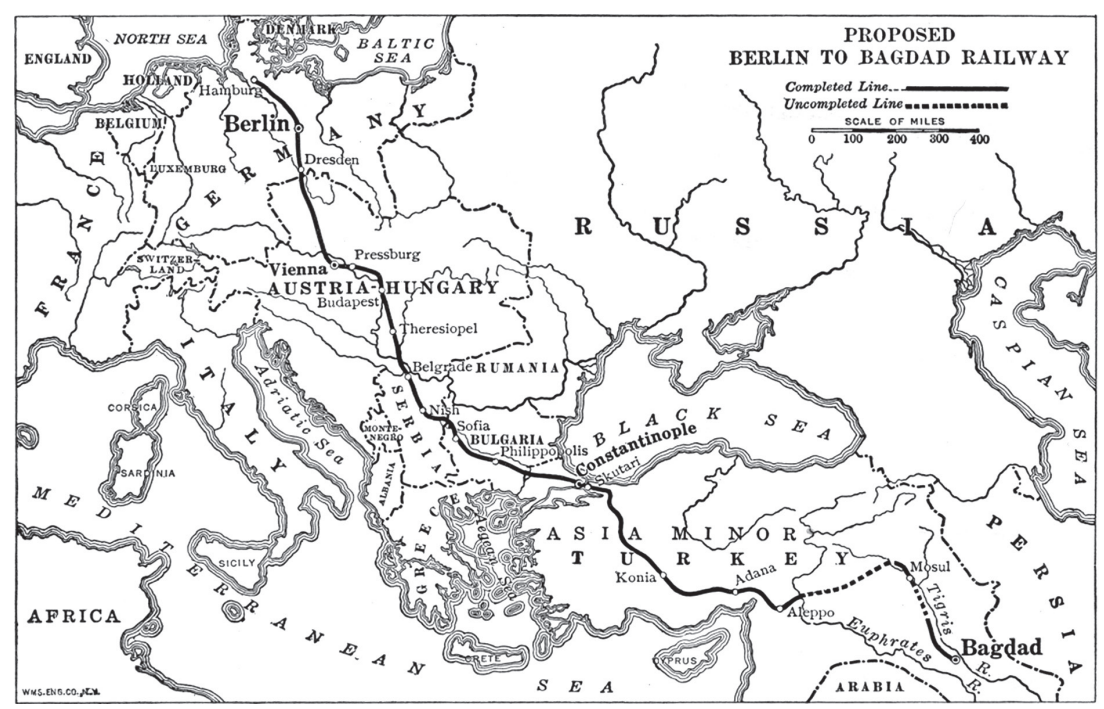

Source: Reprinted from Roland G. Usher, The Story of the Great War, New York: Macmillan, 1919.

\section{Map 1.2 The German interest in South East Europe}

of Serbia. Furthermore, the territorial arrangement created new inequalities in treatment of the Albanians and Macedonians, as the former were granted at least a temporary autonomy under foreign protection, while the latter were simply partitioned between Serbia, Bulgaria and Greece.

The events of 1913 dealt a severe blow to the prospects of Balkan cooperation even between the South Slavs, since the territorial settlements provoked dissatisfaction, recriminations and new animosities. In particular, a joint policy for Serbia and Bulgaria, at the focus of the revolutionary and federal projects in the nineteenth century, suffered from a radical and farreaching rupture after the Macedonian partition.

Visibly, the original political programs inspired by the national idea of people's freedoms nurtured across the nineteenth century were already tainted with imperialist interests. At this juncture, the small regional powers understood not only that they had room for maneuvering without foreign protection in order to expand territorially, but that they could themselves become part of the international balance of power by manipulating the Great Powers for their own purposes.

As a result, on the one hand the Balkan Wars strengthened the strategic advantage of the local winners. They created in the region an unexpected 


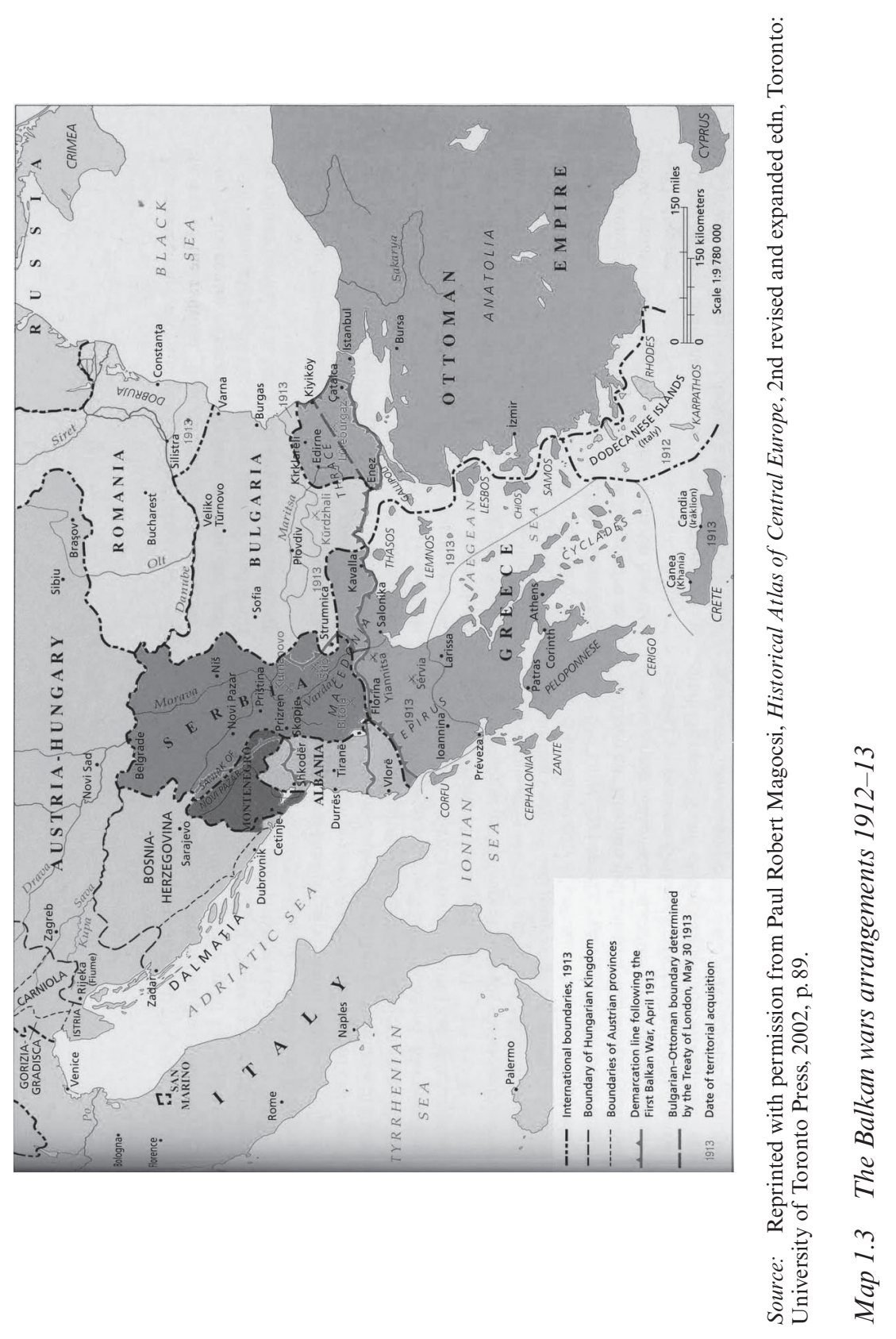


"geopolitical barrier" to the expansionist plans toward the Aegean Sea nurtured in Vienna and Berlin, plans that were, in turn, a key concern of the governments of the Triple Entente. On the other hand, the peace settlements encouraged a concentration of powerful European interests in the Balkans, paving the way for potential greater confrontations.

Meanwhile, the attractiveness of the nineteenth-century ideas based on national freedoms continued to inflame the young revolutionaries, secret organizations and intellectuals by encouraging strong expectations of changes, particularly in Central Europe and in the Balkans. Plans of action designed to "speed up" the process of change, intensified particularly among the youth, who were anxious to follow the examples of the Italian, Polish, Russian and Hungarian revolutionaries of the previous century.

Crucially, despite the imperialistic policies pursued by Great and Small Powers, there were a myriad of underground contacts, exchanges of ideas and readings. As a result, national aspirations increasingly mixed with social and economic revolutionary perspectives. They influenced to a remarkable degree not only the programs of secret societies and newly established political parties or associations, but also the imagination of small groups and individual personalities, who were ready to act even alone.

Within this framework, two cultural dynamics were nurtured between the nineteenth and the twentieth centuries. They roughly identified with the ideals of people's freedom on one side, and the prosaic reality of the imperial policies of either the old multinational dynasties or the nationstate under construction, on the other. They were approaching a merciless clash, although even the borders between them were very porous and, therefore, open to far-reaching and unsettled implications.

Austria-Hungary, in particular, would become the battleground for this intense confrontation. This empire was the subject of a variety of suggested reforms. Austro-Marxists Karl Renner and Otto Bauer promoted cultural autonomy that was not linked to territoriality. In 1906 the lawyer Aurel Popovici forwarded a plan for a multinational federation of peoples, equally protected in their legal status within autonomous regions or states. These proposals, among others, were the focus of domestic political debates, even while the Imperial foreign policy was efficiently pursuing a strategy of territorial expansion toward Constantinople, in evident conflict with the national directives of the small Balkan states.

The heir to the throne, Archduke Franz Ferdinand, was also engaged in designing a transformation of Austria-Hungary. His preference was for a tripartite monarchy. He envisioned a third partner to the existing Dual Monarchy established with the Ausgleich of 1867 with the Hungarian landowners. The "third party" would be the Slavic peoples, or the nonHungarians. Franz Ferdinand, in particular, favored this option with the 
clear aim of reducing the role of the Hungarian landlords, who reciprocated his hostility. On the other hand, the project was also seriously opposed by different social strata of the Empire, because of the persistent centrifugal forces, or the intensifying demands regarding equality for each single people, or other alternative programs, nurtured by a wide range of revolutionary projects.

Actually, the spectrum of necessary reforms was much broader than a mere "makeover" of the "top" constitutional structure of Imperial relations could achieve. Most of the existing Habsburg institutions were still rooted in the Middle Ages, while the claims by the various nationalities for social and political rights, both for individuals and collectivities through the new mass communication systems, were strengthening the expectations for a modern democracy.

In other words, using Zygmunt Bauman's approach, the times were ripe for liquefying the pre-existing social links, and creating new patterns of dependency and interaction.

In this sense, Yugoslavism, the prospective integration of South Slavs with Serbia outside of the Imperial borders, attracted popular interest in the South, similar to Czechoslovakism in the North, following the inspiration of Italian and German unifications. Consequently, the tripartite perspective appeared to be the most relevant barrier to such achievements, because it aimed to preserve the Empire, albeit reformed. At the same time, the network of underground movements that were still haunting the "old Europe" of the pre-modern dynastic multinational monarchies were conspiring to put an end to this world. They nurtured hopes of new uprisings and were confident in the disintegrating impact of tyrannicide.

These beliefs, encoded in the aforementioned revolutionary political culture of the nineteenth century, produced the background that encouraged a young Bosnian student, Gavrilo Princip, to improvise an attack with his friends on 28 June 1914, and succeed in assassinating Archduke Franz Ferdinand in Sarajevo (Dedijer 1966). The aim of Gavrilo Princip was part of the same political culture of the Italians Felice Orsini and Guglielmo Oberdan, or the Russian narodniks who killed Tsar Alexander II. Princip, too, firmly believed that tyrannicide would create the conditions for the unification of the Yugoslavs. In this sense, the most recent identification of Princip's act with a pan-Serbian program is historically groundless. ${ }^{3}$

3 In 2014, celebrating the anniversary of the beginning of World War I, two monuments were built in Belgrade and in Pale with the aim of celebrating Princip as a pan-Serbian hero, while in Sarajevo the Bosniak authorities erased signs of remembrance in the location where the murder occurred and reshaped the content of the museum which was once dedicated to him under the consideration that a terrorist cannot deserve the respect of the international 
On the contrary, he was a "Serbo-Croatian" youth speaking the "Croatian-Serbian language", as he stated during his trial. Moreover, his ideal of people's freedom through "tyrannicide" was confirmed by his repeated apology for accidentally killing the wife of the Archduke, who did not represent, in his view, any specific political obstacle to the project on whose behalf he acted.

At the same time, however, this crime occurred at the precise time that the relations between the two aforementioned cultural dynamics were ready to clash, as the ideals of freedom uncompromisingly confronted the imperialistic designs of the Austro-Hungarian military component of the society. In fact, the murder of the Archduke offered an unexpected opportunity to the belligerent circles in Vienna, which desperately sought a pretext to carry out their imperialistic plans to the south. Thus, they exploited the assassination to declare war on Serbia.

In short order, the accumulation of imperialist interests exploded, and World War I began.

community. Both these interpretations seriously manipulated the cultural context of the event, in search of contemporary political opportunities. 